\title{
PENGARUH PRICE DISCOUNT FRAMING TERHADAP PURCHASE INTENTION PADA RAMAYANA DEPARTMENT STORE, JODOH, BATAM
}

\author{
Diska Nabella Shakti ${ }^{1}$ ), Sri Zuliarni ${ }^{2}$ ) \\ ${ }^{1}$ )Program Studi Administrasi Bisnis, Politeknik Negeri Batam, Batam, Indonesia, email: \\ diskanabella03@gmail.com \\ ${ }^{2}$ )Program Studi Administrasi Bisnis, Politeknik Negeri Batam, Batam, Indonesia, email: \\ sri.zuliarni@polibatam.ac.id
}

\begin{abstract}
Abstrak
Penelitian ini menguji tentang pengaruh price discount framing terhadap purchase intention di Ramayana Department Store, Jodoh, Batam. Responden penelitian ini adalah pengunjung Ramayana Department Store dengan kiteria pernah melakukan kunjungan minimal 2 kali, yaitu sebanyak 107 orang. Metode analisis data yang digunakan adalah analisis deskriptif dengan menggunakan regresi linear berganda, uji asumsi klasik, uji t dan uji $\mathrm{F}$ dengan taraf signifikansi sebesar 0,05 dan koefisien determinasi. Hasil dari penelitian ini adalah keempat variabel independen yaitu percentage discount, absolute saving, bonus pack dan special price secara parsial dan simultan berpengaruh positif signifikan terhadap purchase intention.
\end{abstract}

Kata kunci: price discount framing, purchase intention 
Diska, Sri, Pengaruh Price Discount Framing Terhadap Purchase Intention Pada Ramayana....

\section{PENDAHULUAN}

Promosi merupakan bagian dari kegiatan pemasaraan dikenal sebagai unsur dari bauran pemasaran (marketing mix). Perusahaan sangat memerlukan promosi karena dalam satu pihak meyakinkan konsumen terhadap produk yang ditawarkan sedangkan dipihak lain sangat menentukan suksesnya perusahaan menghadapi banyak persaingan di pasar. Menurut Kotler dan Keller (2010) promosi adalah sarana dimana perusahaan berusaha untuk membujuk, menginformasikan dan mengingatkan konsumen baik secara langsung maupun tidak langsung tentang produk dan merek yang mereka jual.

Salah satu alat promosi yang terbukti ampuh dan memiliki keunggulan adalah price discount atau potongan harga. Menurut Sofjan (2009) mengatakan bahwa diskon merupakan potongan harga, dimana pengurangan tersebut dapat berbentuk tunai atau berupa potongan-potongan yang lain. Biasanya konsumen cenderung menyukai produk yang mempunyai harga lebih murah. Hal tersebut membuat perusahaan seringkali menggunakan promosi penjualan dengan memberikan diskon atau potongan harga besar-besaran bagi produk mereka agar menarik purchase intention konsumen. Jenis promosi yang banyak digunakan salah satunya adalah price discount framing yaitu pesan promosi harga dibingkai dalam sebuah penawaran (Varadarajan et al,2012). Banyak pelaku bisnis yang menerapkan price discount framing, terutama di berbagai department stores. Berikut adalah daftar department store di Kota Batam.

Tabel 1. Daftar Department Stores di Kota Batam

\begin{tabular}{|c|l|}
\hline No. & \multicolumn{1}{|c|}{ Nama Department Store } \\
\hline 1 & PT Matahari Department Store Tbk \\
\hline 2 & PT Ramayana Lestari Sentosa Tbk \\
\hline 3 & Sunboss Department Store \\
\hline
\end{tabular}

Sumber: data olahan, 2018
Ramayana merupakan salah satu department store yang menerapkan price discount framing dan menjadi department store yang cukup digemari oleh masyarakat luas. Berbagai macam bentuk promosi telah dilakukan oleh Ramayana untuk menarik perhatian pengunjung dan meningkatkan volume penjualan. Salah satunya adalah Ramayana Department Store, Jodoh, Batam yang tidak henti-hentinya memberikan price discount framing yang mampu untuk menarik minat konsumen. Berdasarkan wawancara kepada Bapak Iskandar selaku Manager Ramayana Department Store Jodoh, Batam dimana Ramayana menerapkan 4 jenis strategi price discount framing yaitu percentage saving, absolute saving, bonus pack, dan special price promotion.

Berdasarkan uraian latar belakang, maka rumusan masalah penelitian ini adalah bagaimanakah pengaruh percentage discount, absolute saving, bonus pack dan special price secara parsial dan simultan terhadap purchase intention pada Ramayana Department Store, Jodoh, Batam? Sedangkan tujuan penelitian ini adalah untuk mengeahui pengaruh percentage discount, absolute saving, bonus pack dan special price secara parsial dan simultan terhadap purchase intention pada Ramayana Department Store, Jodoh, Batam.

\section{KAJIAN TEORI}

Untuk menunjang penelitian yang akan dilakukan oleh penulis, penulis menggunakan referensi dari hasil penelitian terdahulu yang relevan, seperti informasi pada tabel 2 berikut. 
Journal of Applied Business Administration Vol 3, No 1, Maret 2019, hlm. 132-147.

Tabel 2. Daftar Penelitian Terdahulu yang Relevan

\begin{tabular}{|c|c|c|c|c|c|}
\hline No & $\begin{array}{c}\text { Penulis Penelitian } \\
\text { dan Tahun }\end{array}$ & Judul Penelitian & Variabel & $\begin{array}{c}\text { Teknik Analisis } \\
\text { Data }\end{array}$ & Hasil Penelitian \\
\hline 1 & $\begin{array}{l}\text { Charis Gumelar } \\
\text { (Universitas } \\
\text { brawijaya Malang, } \\
\text { 2016) }\end{array}$ & $\begin{array}{l}\text { Pengaruh } r \text { Price } \\
\text { Discount } \text { Framing } \\
\text { (Nominal Persentase } \\
\text { Dan Teks) terhadap } \\
\text { Purchase Intention } \\
\text { yang Dimediasi oleh } \\
\text { Persepsi Konsumen } \\
\text { pada Produk Sepatu } \\
\text { di Sport Station } \\
\text { Malang (Studi Pada } \\
\text { Mahasiswa } \\
\text { Universitas } \\
\text { Brawijaya Malang) }\end{array}$ & $\begin{array}{l}\text { Price discount } \\
\text { framing (X), } \\
\text { Purchase } \\
\text { intention }(Y)\end{array}$ & $\begin{array}{l}\text { Analisis jalur (path } \\
\text { analysis) }\end{array}$ & $\begin{array}{lr}\text { Price } & \text { discount } \\
\text { framing } & \text { berpengaruh } \\
\text { positif dan } & \text { signifikan } \\
\text { terhadap } & \text { persepsi } \\
\text { konsumen. } & \text { Persepsi } \\
\text { konsumen } & \\
\text { berpengaruh } & \text { positif } \\
\text { dan } & \text { signifikan } \\
\text { terhadap } & \text { purchase } \\
\text { intention. } & \text { price } \\
\text { discount } & \text { framing } \\
\text { berpengaruh } & \text { positif } \\
\text { dan } & \text { signifikan } \\
\text { terhadap } & \text { purchase } \\
\text { intention. } & \text { Sedangkan } \\
\text { jika } & \text { melalui } \\
\text { pengaruh } & \text { tidak } \\
\text { langsung, } & \text { persepsi } \\
\text { konsumen } & \text { secara } \\
\text { positif dan } & \text { signifikan } \\
\text { memediasi } & \text { pengaruh } \\
\text { price } & \text { discount } \\
\text { framing } & \text { terhadap } \\
\text { purchase intention. }\end{array}$ \\
\hline 2 & 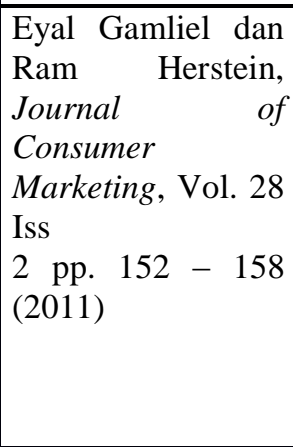 & $\begin{array}{l}\text { To save or to } \\
\text { lose: does framing } \\
\text { price promotion } \\
\text { affect } \\
\text { consumers' } \\
\text { intentions? }\end{array}$ & $\begin{array}{l}\text { Positive } \\
\text { framing } \\
\text { (X1), } \\
\text { Negative } \\
\text { framing } \\
\text { (X2), } \\
\text { Dependen: } \\
\text { Department } \\
\text { Store } \\
\text { (Y) }\end{array}$ & Two Way ANOVA & $\begin{array}{lr}\text { Partisipan } & \text { tidak } \\
\text { menunjukkan } & \\
\text { keinginan } & \text { untuk } \\
\text { membeli } & \text { produk } \\
\text { yang } & \\
\text { ditawarkan } & \text { pada } \\
\text { promosi } & \text { penjualan } \\
\text { diskon } & \text { ketika } \\
\text { dipersentasikan } & \\
\text { dengan } & \text { negative } \\
\text { frame. } & \end{array}$ \\
\hline 3 & $\begin{array}{lr}\text { Sally } & \text { McKechnie, } \\
\text { James } & \text { Devlin, } \\
\text { Christine } & \text { Ennew, } \\
\text { dan } & \\
\text { Andrew } & \text { Smith } \\
(2012), & \\
\begin{array}{l}\text { European } \\
\text { of }\end{array} \\
\begin{array}{l}\text { Marketing, } \\
\text { Iss }\end{array} \\
\begin{array}{l}11 / 12 \\
1522\end{array} & \text { pol. } 46 \\
1501 & - \\
\end{array}$ & $\begin{array}{l}\text { Effects of } \\
\text { discount framing in } \\
\text { comparative price } \\
\text { advertising", }\end{array}$ & $\begin{array}{l}\text { Discount size } \\
\text { (X1), } \\
\text { Discount } \\
\text { format } \\
\text { (X2), } \\
\text { Transaction } \\
\text { value } \\
\text { (Y1), } \\
\text { Department } \\
\text { Store } \\
\text { (Y2). }\end{array}$ & $\begin{array}{l}\text { Multivariate analy } \\
f \quad \text { covariance } \\
\text { MANCOVA) }\end{array}$ & $\begin{array}{l}\text { Efek dari diskon } \\
\text { framing dalam } \\
\text { promosi dipengaruhi } \\
\text { oleh ukuran diskon } \\
\text { dalam konteks low- } \\
\text { product tidak pada } \\
\text { high-product. }\end{array}$ \\
\hline
\end{tabular}

Sumber: Gumelar (2016), Gamliel dan Herstein (2011), McKechnie et al (2012) 
Diska, Sri, Pengaruh Price Discount Framing Terhadap Purchase Intention Pada Ramayana....

\section{Bauran Pemasaran (Marketing Mix)}

Menurut Sumarmi dan Soeprihanto (2010), marketing mix adalah kombinasi dari variabel atau kegiatan inti dari sistem pemasaran yaitu produk, harga, promosi, dan distribusi.

1. Product (produk)

Produk adalah setiap apa saja yang bisa ditawarkan di pasar untuk mendapatkan perhatian, permintaan, konsumsi yang dapat memenuhi keinginan atau kebutuhan. Produk tidak hanya selalu berupa barang tetapi bisa juga berupa jasa ataupun gabungan dari barang dan jasa.

2. $\quad$ Price (harga)

harga adalah jumlah uang (ditambah beberapa produk jika mungkin) yang diperlukan untuk mendapatkan sejumlah kombinasi dari barang beserta pelayanannya.

3. Place (tempat)

Yang dimaksud tempat dalam marketing mix biasa disebut dengan saluran distribusi yaitu saluran dimana produk tersebut sampai kepada konsumen. Definisi dari Sumarni dan Soeprihanto (2010) tentang saluran distribusi adalah saluran yang dipergunakan oleh produsen untuk menyalurkan produk dari produsen sampai ke konsumen atau industri pemakai.

4. Promotion (promosi)

Pada hakikatnya promosi adalah suatu bentuk komunikasi pemasaran (Tjiptono, 2008). Komunikasi pemasaran adalah aktivitas pemasaran yang berusaha membagikan informasi, mempengaruhi atau membujuk, dan atau mengingatkan pasar sasaran atas perusahaan dan produknya, agar bersedia menerima, membeli, dan loyal pada produk yang ditawarkan perusahaan.
Berdasarkan teori-teori diatas, maka dapat penulis simpulkan bahwa bauran pemasaran adalah suatu kelompok komposisi pemasaran yang terdiri dari $4 \mathrm{P}$ yaitu product, price, place dan promotion yang saling memiliki keterkaitan satu dengan yang lainnya yang memiliki tujuan untuk memenuhi kebutuhan-kebutuhan dan kepuasan konsumennya serta untuk mencapai tujuan perusahaan.

\section{Harga}

Menurut Kotler dan Armstrong (2013), harga merupakan sejumlah uang yang dibebankan atas suatu barang atau jasa atau jumlah dari nilai uang yang ditukar konsumen atas manfaat-manfaat karena memiliki atau menggunakan produk atau jasa tersebut. Berikut adalah strategi penyesuaian harga (Kotler dan Armstrong, 2010):

1) Penetapan harga diskon bertujuan untuk menghargai respon pelanggan seperti membayar lebih awal atau mempromosikan produk.

2) Penetapan harga tersegmentasi yaitu menyesuaikan harga untuk memungkinkan adanya perbedaan dalam produk, pelanggan dan lokasi.

3) Penetapan harga psikologis yaitu menyetarakan harga untuk pengaruh psikologis.

4) Penetapan harga promosi yaitu mengurangi harga untuk sementara agar dapat meningkatkan penjualan jangka pendek.

\section{Diskon Bingkai Harga ( Price Discount Framing )}

Framing atau pembingkaian adalah suatu hal yang dapat meningkatkan dampak tanggapan atau respon masyarakat dari sebuah presentasi (Wu dan Cheng, 2011). Pada framing, titik referensi ini menjadi "bingkai" seseorang dalam mempertimbangkan banyak kemungkinan yang akan terjadi. Kemungkinan- 
Journal of Applied Business Administration Vol 3, No 1, Maret 2019, hlm. 132-147.

kemungkinan yang telah terbingkai itulah yang nantinya akan dievaluasi oleh pemilih.

Bagi perusahaan, framing adalah salah satu cara untuk memancing ketertarikan sebanyak-banyaknya tanpa mempunyai maksud untuk membohongi konsumenkonsumen. Peritel menyampaikan kebenaran meskipun dikemas sedemikian rupa dengan bingkai yang cantik. Hal tersebut tidaklah salah karena termasuk dalam seni price framing. Konsumen tidak dapat dikatakan merugi, bahkan konsumen akan merasa untung dengan melihat adanya selisih dari titik referensi dengan harga yang mereka bayar.

Keberagaman bentuk-bentuk framing akan mengarahkan konsumen terhadap evaluasi yang berbeda. Dalam artikel yang ditulis oleh Kahneman dan Tversky dalam Pandora et al., (2012), menunjukkan jika price discount framing yang dilakukan untuk kegiatan promosi dapat memengaruhi pengambilan keputusan dan penilaian kognitif dari konsumen. Retailer sering mencoba mempengaruhi persepsi konsumen dan intens membeli dengan membuat variasi bentuk dari diskon dan juga cara membingkai promosi.

Terdapat banyak text discount untuk menyatakan harga diskon. Contohnya harga diskon yang dinyatakan dalam bentuk persentase dan dalam bentuk moneter (rupiah). Dalam beberapa kasus, harga diskon dapat dikemas dengan Bonus Pack seperti "buy one, get one free" atau "two for the price of one" dan tidak sedikit juga yang menerapakan dalam bentuk Special Price atau potongan harga dengan nominal tertentu yang biasanya diterapkan ketika hari-hari besar, akhir pekan atau jam-jam tertentu. Sebuah efek dari framing dikatakan terjadi apabila menimbulkan deskripsi yang berbeda dari suatu situasi yang sama sehingga membuat preferensi yang berbeda pula.

1. Percentage discount (persentase)

Menurut Gamliel dan Herstein (2011), discount framing yang dinyatakan dalam persentase merupakan salah satu jenis dari promosi moneter. McKechnie et al., (2012), persentase merupakan salah satu cara yang digunakan retailer dalam membingkai message framing mereka. Dalam discount framing berupa persentase (percentage discount), retailer biasanya membingkai harga mereka seperti "diskon 50\%" atau "save 10\%".

2. Absolute saving (absolut atau nominal) Price discount framing berupa Absolute Saving dinyatakan dalam bentuk nominal (dalam hal ini rupiah). Pada Absolute Saving, retailer memberikan harga awal yang lebih tinggi kemudian mencoret harga tersebut dan menggantikan dengan harga yang lebih rendah (McKechnie et al., 2012). Misalnya harga awal Rp 200.000,00 yang dicoret kemudian menuliskan harga baru sebesar Rp150.000,00 sebagai pengganti harga tersebut.

3. Bonus pack (paket bonus)

Buy one get one free atau buy two get one free termasuk dalam discount framing berupa Bonus Pack atau paket bonus dimana ketika konsumen membeli barang akan mendapatkan satu tambahan produk dengan harga yang tidak berubah dari harga semula. Pembelian produk dengan Bonus Pack Promotion sangat menguntungkan karena mereka mendapatkan kuantitas atau produk tambahan dengan harga normal atau harga serupa ketika konsumen melakukan pembelian ketika tidak ada promosi Bonus Pack . Menurut Clow dan Baack (2012), pelanggan menikmati Bonus Pack karena rasanya seperti mereka mendapatkan gratis barang dagangan. Nilai tambahan Bonus Pack umumnya jelas bagi konsumen dan dapat memiliki dampak yang kuat pada keputusan pembelian. 
Diska, Sri, Pengaruh Price Discount Framing Terhadap Purchase Intention Pada Ramayana....

4. $\quad$ Special price (harga spesial)

Special price adalah potongan harga dengan waktu dan nominal tertentu. Price framing ini termasuk dalam kategori promotion point purchase yaitu menyediakan titik/pusat pembelian yang tidak permanen untuk produk yang sedang dipromosikan (Kotler dan Amstrong, 2002)

\section{Purchase Intention (Niat Beli)}

Menurut Assael (2002), purchase intention merupakan kecenderungan konsumen untuk membeli suatu merek atau mengambil tindakan yang berhubungan dengan pembelian yang diukur dengan tingkat kemungkinan konsumen melakukan pembelian. Menurut Bearman (2007) tumbuhnya purchase intention konsumen disebabkan oleh unsur-unsur yang terdiri dari tiga tahapan, diantaranya :

1. Rangsangan yaitu suatu isyarat yang ditunjukan untuk mendorong atau menimbulkan seseorang untuk bertindak.

2. Kesadaran yaitu sesuatu yang memasuki pikiran seseorang. Kesadaran ini dipengaruhi oleh pertimbangan atas barang atau jasa itu sendiri.

3. Pencarian Informasi yaitu aspek pencarian informasi dibagi menjadi enam bagian:

a. Informasi intern adalah informasi bersumber dari ingatan konsumen untuk memilih barang atau jasa yang memuaskannya.

b. Informasi ekstern adalah informasi yang melibatkan iklan (media cetak dan penjualan langsung, dan bersumber sosial atau keluarga, teman ataupun kolega.

c. Memastikan sifat yang dari setiap pilihan yang ada tahap ini konsumen mengumpulkan informasi yang berhubungan dengan ciri dan sifat dari setiap pilihan. Setelah diketahui pilihannya maka konsumen akan memutuskan barang yang akan dibelinya.

d. Pemilihan alternatif, pemilihan ini terjadi jika beberapa barang atau jasa merupakan suatu pilihan yang sulit bagi konsumen untuk mengevaluasi alternatif yang tersedia.

e. Pembelian tahapan di mana konsumen telah melalui pilihan dan siap untuk mengeluarkan uangnya untuk ditukar dengan barang atau jasa tersebut.

f. Tempat pembelian merupakan salah satu perkembangan di toko mana konsumen akan membeli produk atau jasa tesebut. Sebuah toko atau penyalur berupaya memiliki citra yang baik atau merangsang konsumen untuk berbelanja lebih lanjut sehingga diharapkan konsumen menjadi terbiasa membeli di tempat yang sama.

\section{Faktor-faktor yang Mempengaruhi Purchase Intention Konsumen}

Menurut Swastha (2008) mengemukakan faktor-faktor yang mempengaruhi niat membeli berhubungan dengan perasaan dan emosi, bila seseorang merasa senang dan puas dalam membeli barang atau jasa maka hal itu akan memperkuat minat membeli, ketidakpuasan biasanya menghilangkan minat.

\section{Kerangka Pemikiran}

Kerangka pemikiran penelitian seperti pada gambar 1 berikut. 
Journal of Applied Business Administration Vol 3, No 1, Maret 2019, hlm. 132-147.

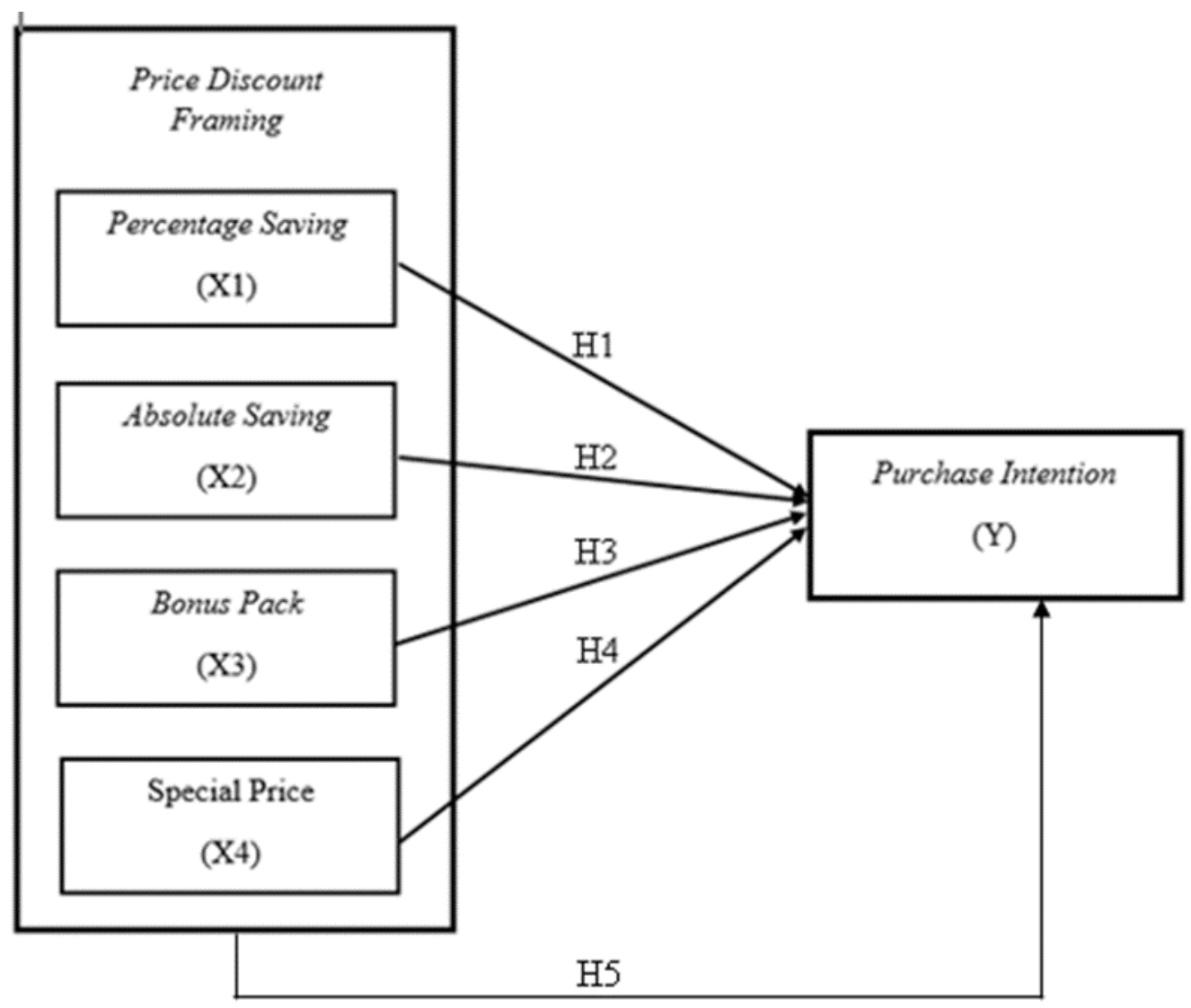

Gambar 1. Kerangka Pemikiran Penelitian Sumber: data olahan, 2018

Berdasarkan perumusan masalah dan kajian empiris yang telah dilakukan sebelumnya, maka hipotesis yang diajukan dalam penelitian ini yaitu:

1. H1 Percentage saving (persentase) mempunyai pengaruh positif dan signifikan untuk menarik purchase intention konsumen

2. $\mathrm{H} 2$ Absolute saving (nominal) mempunyai pengaruh positif dan signifikan untuk menarik purchase intention konsumen

3. H3 Bonus pack (teks) mempunyai pengaruh positif dan signifikan untuk menarik purchase intention konsumen

4. H4 special price mempunyai pengaruh positif dan signifikan untuk menarik purchase intention konsumen

5. H5 percentage discount, absolute saving, bonus pack, special price mempunyai pengaruh yang positif dan signifikan untuk menarik purchase intention konsumen.

\section{METODE}

Analisis data bersifat kuantitatif atau statistik dengan tujuan untuk menguji hipotesis yang telah ditetapkan (Sugiyono, 2014). Objek dan ruang lingkup dalam penelitian yang peneliti lakukan ini adalah pengunjung Ramayana Department Store yang pernah berkunjung ke Ramayana Department Store minimal 2 (dua) kali. Sedangkan operasionalisasi variabel seperti pada tabel 3 berikut. 
Diska, Sri, Pengaruh Price Discount Framing Terhadap Purchase Intention Pada Ramayana....

Tabel 3. Operasionalisasi Variabel Penelitian

\begin{tabular}{|c|c|c|c|}
\hline Variabel & Dimensi & Indikator & Skala Pengukuran \\
\hline $\begin{array}{l}\text { Percentage discount (X1) } \\
\text { discount framing yang } \\
\text { dinyatakan dalam persentase } \\
\text { dan merupakan salah satu } \\
\text { jenis dari promosi moneter } \\
\text { pada Ramayana Department } \\
\text { Store, Jodoh, Batam }\end{array}$ & $\begin{array}{l}\text { Potongan harga } \\
\text { persentase }\end{array}$ & $\begin{array}{l}\text { 1. Menyukai potongan harga } \\
\text { dalam bentuk persentase } \\
\text { 2. Kemungkinan akan membeli } \\
\text { produk yang mempunyai } \\
\text { diskon dalam bentuk } \\
\text { persentase }\end{array}$ & Ordinal \\
\hline $\begin{array}{l}\text { Absolute saving (X2) } \\
\text { Price discount framing } \\
\text { berupa absolute saving } \\
\text { dinyatakan dalam bentuk } \\
\text { nominal yang ditawarkan } \\
\text { oleh Ramayana Department } \\
\text { Store, Jodoh, Batam }\end{array}$ & $\begin{array}{l}\text { Potongan harga } \\
\text { nominal }\end{array}$ & $\begin{array}{l}\text { 1. Menyukai potongan harga } \\
\text { dalam bentuk nominal } \\
\text { 2. Kemungkinan akan membeli } \\
\text { produk yang mempunyai } \\
\text { diskon dalam bentu nominal }\end{array}$ & Ordinal \\
\hline $\begin{array}{l}\text { Bonus pack (X3) } \\
\text { Pembelian produk dengan } \\
\text { Bonus pack promotion sangat } \\
\text { menguntungkan } r \text { karena } \\
\text { mereka mendapatkan } \\
\text { kuantitas atau produk } \\
\text { tambahan dengan harga } \\
\text { normal atau harga serupa } \\
\text { ketika konsumen melakukan } \\
\text { pembelian ketika tidak ada } \\
\text { promosi bonus pack. }\end{array}$ & Buy two get one & $\begin{array}{l}\text { 1. Tertarik dengan produk yang } \\
\text { mempunyai tag line buy one } \\
\text { get one } \\
\text { 2. Kemungkinan akan membeli } \\
\text { produk dengan produk yang } \\
\text { berlabel buy one get one } \\
\text { 3. Tertarik dengan produk yang } \\
\text { mempunyai tag line buy two } \\
\text { get one } \\
\text { 4. Kemungkinan akan membeli } \\
\text { produk dengan produk yang } \\
\text { berlabel buy one get one }\end{array}$ & Ordinal \\
\hline $\begin{array}{l}\text { Special price (X4) } \\
\text { Special price adalah } \\
\text { potongan harga dengan } \\
\text { nominal dan waktu tertentu. } \\
\text { yang sifatnya tidak permanen } \\
\text { untuk produk yang sedang } \\
\text { dipromosikan oleh Ramayana } \\
\text { Department Store, Jodoh, } \\
\text { Batam }\end{array}$ & $\begin{array}{l}\text { Potongan } \\
\text { harga dengan } \\
\text { nominal dan waktu } \\
\text { tertentu }\end{array}$ & $\begin{array}{ll}\text { 1. } & \text { Waktu-waktu tertentu } \\
\text { 2. } & \text { Harga khusus }\end{array}$ & Ordinal \\
\hline $\begin{array}{l}\text { Purchase intention (Y) } \\
\text { Purchase intention adalah } \\
\text { sesuatu hal yang mewakili } \\
\text { konsumen Ramayana } \\
\text { Department Store yang } \\
\text { mempunyai kemungkinan, } \\
\text { akan, rencana atau bersedia } \\
\text { untuk membeli suatu produk } \\
\text { atau layanan di masa depan. }\end{array}$ & $\begin{array}{l}\text { 1. Attention } \\
\text { 2. Interest } \\
\text { 3. Desire } \\
\text { 4. Action }\end{array}$ & $\begin{array}{l}\text { Ketertarikan konsumen untuk } \\
\text { melihat produk } \\
\text { 2. } \begin{array}{l}\text { Rasa ingin tahu lebih } \\
\text { terhadap produk }\end{array} \\
\text { 3. Keinginan untuk memiliki } \\
\text { produk } \\
\text { 4. } \begin{array}{l}\text { Tindakan untuk mengambil } \\
\text { keputusan }\end{array}\end{array}$ & Ordinal \\
\hline
\end{tabular}

Sumber: data olahan, 2018 
Journal of Applied Business Administration Vol 3, No 1, Maret 2019, hlm. 132-147.

Populasi dalam penelitian ini adalah seluruh pengunjung Ramayana yang mempunyai purchase intention produk di Ramayana Department Store, Jodoh, Batam dengan besarnya populasi merupakan jumlah rata-rata pengunjung di Ramayana setiap bulan adalah \pm 4.400 orang. Kemudian peneliti membagi lagi dengan jumlah hari dalam 1 bulan yaitu 4.400/30 = 146,66 (147) setiap harinya di Ramayana Department Store, Jodoh, Batam yang berada di Jl. Komplek Jodoh Marina, Lubuk Baja Kota, Lubuk Baja, Kota Batam, Kepulauan Riau 29432.

Sampel dalam penelitian ini menggunakan teknik purposive sampling method. Menurut Sugiyono (2013), purposive sampling adalah teknik pengambilan sampel dengan pertimbangan tertentu. Penentuan jumlah sampel menggunakan rumus slovin, sehingga didapat sampel dalam penelitian ini adalah 107 orang. Teknik pengumpulan data yang digunakan dalam penelitian ini menggunakan teknik kuesioner.

Statistik deskriptif digunakan untuk memberikan gambaran atau deskripsi profil data sampel yang dilihat dari nilai rata-rata (mean), median, maksimum, minimum, dan standar deviasi. Untuk menginterprestasikan data maka kelas tanggapan dibagi menjadi empat yaitu sangat baik, baik, tidak baik dan sangat tidak baik. Untuk menentukan interval nilai, menggunakan rumus dikemukakan oleh Daryanto yang dikutip oleh Ramadhona (2010) yaitu:

$P=\frac{\text { Rentang }}{\text { Banyaknya kelas }}$

Keterangan :

$\mathrm{P}=$ Rentang Skala

Rentang $=$ skor tertinggi - skor terendah

Banyak kelas $=$ jumlah kelas interval

$$
P=\frac{4-1}{4}=0,75
$$

Maka nilai untuk interval terendah yaitu sangat tidak baik adalah :

$=$ skor terendah $+\mathrm{p}$

$=1+0,75$

$=1,75$

Sehingga nilai untuk interval terendah adalah 1 sampai 1,75

Nilai untuk interval tidak baik $\quad=(1,75$

$+0,01)$ sampai $(1,75+0,75)$

$=1,76$ sampai 2,50

Nilai untuk interval baik

$+0,01)$ sampai $(2,50+0,75)$

$=2,51$ sampai 3,25

Nilai untuk interval sangat baik $=(3,25$

$+0,01)$ sampai $(3,25+0,75)$

$=3,26$ sampai 4,00

Hasil perhitungan batas interval dan kategori pilihan dapat dilihat pada tabel 4 .

Tabel 1 Batas Interval dan Kategori Pilihan

\begin{tabular}{|c|c|c|}
\hline No & Batas Interval & Kategori Pilihan \\
\hline 1 & $1,00-1,75$ & Sangat tidak baik \\
\hline 2 & $1,76-2,50$ & Tidak baik \\
\hline 3 & $2,51-3,25$ & Baik \\
\hline 4 & $3,26-4,00$ & Sangat Baik \\
\hline
\end{tabular}

Sumber : Daryanto, 2010

\section{HASIL DAN PEMBAHASAN}

Berdasarkan dari hasil penyebaran kuesioner yang didapat maka selanjutnya para pengunjung yang telah melakukan pengisian kuesioner akan dideskripsikan untuk mengetahui profil mereka menurut jenis kelamin, usia, status, jumlah pendapatan perbulan, dan frekuensi berkunjung ke Ramayana Department Store, Jodoh, Batam.

Distribusi jenis kelamin responden akan membagi responden ke dalam kategori laki-laki dan perempuan. Jumlah responden laki-laki sebanyak 25,2\%, sementara responden perempuan sebanyak $74,8 \%$. Hasil ini menunjukkan bahwa pengunjung 
perempuan lebih banyak yang melakukan kunjungan ke Ramayana Department Store dibandingkan pengunjung laki-laki. Hal ini dipengaruhi oleh faktor minat belanja perempuan lebih tinggi daripada perempuan.

Berdasarkan pengelompokan responden menurut usia, menunjukkan bahwa jumlah pengunjung Ramayana Department Store yang berusia $<20$ tahun sebanyak 13,1\%, jumlah pengunjung Ramayana Department Store yang berusia 20-30 tahun sebanyak 43\% dan 30-40 tahun sebanyak $28 \%$, dan jumlah pengunjung Ramayana Department Store yang berusia $>40$ tahun sebanyak 15,9\%. Hal ini disebabkan karena pengunjung yang berusia 20-30 tahun mempunyai sifat konsumtif yang tinggi, rasa ingin tahu yang besar dan rasa ingin memiliki produk terlebih apabila melihat produk dengan potongan harga.

Berdasarkan data jumlah pendapatan per bulan para responden menunjukkan bahwa sebagian besar pengunjung yang mempunyai jumlah pendapatan perbulan $<\mathrm{Rp} \quad 1.000 .000$ mempunyai persentase sebesar $11 \%$, pengunjung yang mempunyai Jumlah Pendapatan perbulan sebesar Rp 1.100 .000 s.d Rp 5.000.000 mempunyai persentase sebesar 39\%, pengunjung yang mempunyai pendapatan perbulan sebesar $\mathrm{Rp}$ 5.100 .000 s.d Rp 10.000.000 mempunyai persentase sebesar $40 \%$ sedangkan pengunjung yang mempunyai pendapatan > Rp 10.000.000 mempunyai persentase sebesar 9\%. Hal ini dipengaruhi oleh kota Batam yang menjadi kota Industri yang ratarata mempunyai pendapatan antara $\mathrm{Rp}$ 5.100.000 s.d Rp 10.000.000.

Berdasarkan data frekuensi kunjungan menunjukkan bahwa jumlah pengunjung yang mengunjungi Ramayana Department Store dalam satu tahun sebanyak 2 kali sebesar 15,9\%, jumlah pengunjung yang mengunjungi sebanyak 3-5 kali sebesar $34,6 \%$, jumlah pengunjung yang mengunjungi Ramayana Department Store sebanyak 6-8 kali dalam setahun sebesar $32,7 \%$ dan pengunjung yang mengunjungi Ramayana Department Store lebih dari 8 kali sebesar $16,8 \%$. Hal ini menunjukkan bahwa pengunjung Ramayana akan cenderung kembali mengunjungi Ramayana Department Store sebanyak 3-5 kali dalam setahun.

Analisis deskriptif variabel percentage discount dapat dilihat dari hasil nilai frekuensi dan skor jawaban responden terhadap pernyataan yang digunakan untuk mengukur percentage discount. Perhitungan selengkapnya dapat dilihat pada tabel 5 berikut : 
Journal of Applied Business Administration Vol 3, No 1, Maret 2019, hlm. 132-147.

Tabel 5. Tanggapan Responden mengenai Percentage Discount pada Ramayana Department Store, Jodoh, Batam

\begin{tabular}{|c|c|c|c|c|c|c|c|c|c|c|}
\hline \multirow{3}{*}{ Nomor } & \multirow{3}{*}{ Pernyataan } & \multicolumn{9}{|c|}{ Frekuensi dan Skor Tanggapan Percentage discount } \\
\hline & & \multicolumn{2}{|c|}{ STS } & \multicolumn{2}{|l|}{$\mathrm{TS}$} & \multicolumn{2}{|l|}{$S$} & \multicolumn{2}{|l|}{ SS } & \multirow{2}{*}{$\begin{array}{l}\text { Rata-Rata } \\
\text { (Mean) }\end{array}$} \\
\hline & & $\mathrm{F}$ & Skor & $\mathrm{F}$ & Skor & $\mathrm{F}$ & Skor & $\mathrm{F}$ & Skor & \\
\hline P1 & $\begin{array}{lr}\begin{array}{l}\text { Saya } \\
\text { diskon }\end{array} & \text { Menyukai } \\
\text { persentase }(\%) & \text { harga } \\
\end{array}$ & 5 & 5 & 23 & 46 & 44 & 132 & 35 & 140 & 3,02 \\
\hline $\mathrm{P} 2$ & $\begin{array}{lr}\text { Produk } & \text { yang } \\
\text { mempunyai } & \text { diskon } \\
\text { persentase }(\%) & \text { sangat } \\
\text { menarik } & \end{array}$ & 15 & 15 & 16 & 32 & 55 & 165 & 21 & 84 & 2,77 \\
\hline P3 & 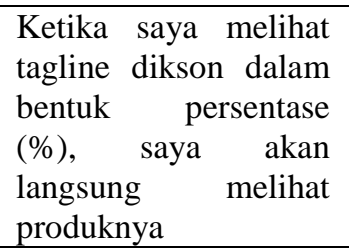 & 0 & 0 & 17 & 34 & 75 & 225 & 15 & 60 & 2,98 \\
\hline P4 & $\begin{array}{l}\text { Saya lebih tertarik } \\
\text { diskon persentase }(\%) \\
\text { dibandingkan dengan } \\
\text { jenis diskon lainnya }\end{array}$ & 0 & 0 & 17 & 34 & 59 & 177 & 31 & 124 & 3,13 \\
\hline \multicolumn{10}{|c|}{ Nilai rata-rata tanggapan responden } & 2,98 \\
\hline
\end{tabular}

Sumber: data olahan, 2018

Penilaian responden terhadap percentage discount adalah baik, yang dapat dilihat dari nilai rata-rata sebesar 2,98. Penilaian tertinggi diberikan kepada item yang menyatakan bahwa Saya lebih tertarik diskon persentase (\%) dibandingkan dengan jenis diskon lainnya sebesar 3,13 . termasuk dalam kategori baik, berarti responden tertarik diskon yang menampilkan persentase dibandingkan dengan jenis diskon yang lain. Sedangkan penilaian terendah diberikan

Tabel 6 Tanggapan Responden mengenai Absolute Saving pada Ramayana Department Store, Jodoh, Batam

\begin{tabular}{|c|c|c|c|c|c|c|c|c|c|c|}
\hline \multirow{3}{*}{ Nomor } & \multirow{3}{*}{ Pernyataan } & \multicolumn{9}{|c|}{ Frekuensi dan Skor Tanggapan Absolute Saving } \\
\hline & & \multicolumn{2}{|c|}{ STS } & \multicolumn{2}{|l|}{ TS } & \multicolumn{2}{|l|}{$S$} & \multicolumn{2}{|c|}{ SS } & \multirow{2}{*}{$\begin{array}{l}\text { Rata- } \\
\text { Rata } \\
\text { (Mean) }\end{array}$} \\
\hline & & $\mathrm{F}$ & Skor & $\mathrm{F}$ & Skor & $\mathrm{F}$ & Skor & $\mathrm{F}$ & Skor & \\
\hline P5 & $\begin{array}{l}\text { Saya menyukai diskon } \\
\text { harga langsung } \\
\text { mencoret harga awal) }\end{array}$ & 1 & 1 & 16 & 32 & 69 & 207 & 21 & 84 & 3,03 \\
\hline P6 & $\begin{array}{l}\text { Produk yang mempunyai } \\
\text { diskon harga sangat } \\
\text { menarik }\end{array}$ & 0 & 0 & 22 & 44 & 60 & 180 & 25 & 100 & 3,03 \\
\hline
\end{tabular}


Diska, Sri, Pengaruh Price Discount Framing Terhadap Purchase Intention Pada Ramayana....

\begin{tabular}{|c|c|c|c|c|c|c|c|c|c|c|}
\hline P7 & $\begin{array}{l}\text { Ketika saya melihat } \\
\text { tagline diskon dalam } \\
\text { bentuk coretan harga, } \\
\text { saya akan langsung } \\
\text { melihat produknya }\end{array}$ & 5 & 5 & 51 & 102 & 47 & 141 & 4 & 16 & 2,47 \\
\hline P8 & $\begin{array}{l}\text { Saya lebih memilih } \\
\text { diskon dengan coretan } \\
\text { harga dibandingkan jenis } \\
\text { diskon lainnya }\end{array}$ & 1 & 1 & 44 & 88 & 53 & 159 & 9 & 36 & 2,65 \\
\hline \multicolumn{2}{|c|}{ Nilai rata-rata tanggapan responden } & & & & & & & & & 2,80 \\
\hline
\end{tabular}

Sumber: Data olahan, 2018

Penilaian responden terhadap absolute saving adalah baik, dapat dilihat dari nilai rata-rata sebesar 2,80. Item yang menyatakan bahwa Saya menyukai diskon harga langsung (mencoret harga awal) dan Produk yang mempunyai diskon harga sangat menarik sama-sama mempunyai penilaian tertinggi yang diberikan oleh responden dengan nilai rata-rata sebesar 3.03 (baik), berarti responden menyukai diskon harga langsung dan berpendapat jika produk yang mempunyai diskon harga langsung sangat menarik. Sedangkan penilaian terendah terdapat pada pernyataan ketika saya melihat tagline diskon dalam bentuk coretan harga, saya akan langsung melihat produknya sebesar 2.47 (tidak baik), hal ini karena ketika melihat tagline diskon dalam bentuk coretan harga, biasanya responden akan berpikir lagi untuk melihat produknya. Sedangkan tanggapan responden terhadap pertanyaan dalam menilai pelaksanaan bonus pack dapat dilihat pada tabel 7 berikut.

Tabel 7 Tanggapan responden mengenai Bonus Pack pada Ramayana Department Store, Jodoh, Batam

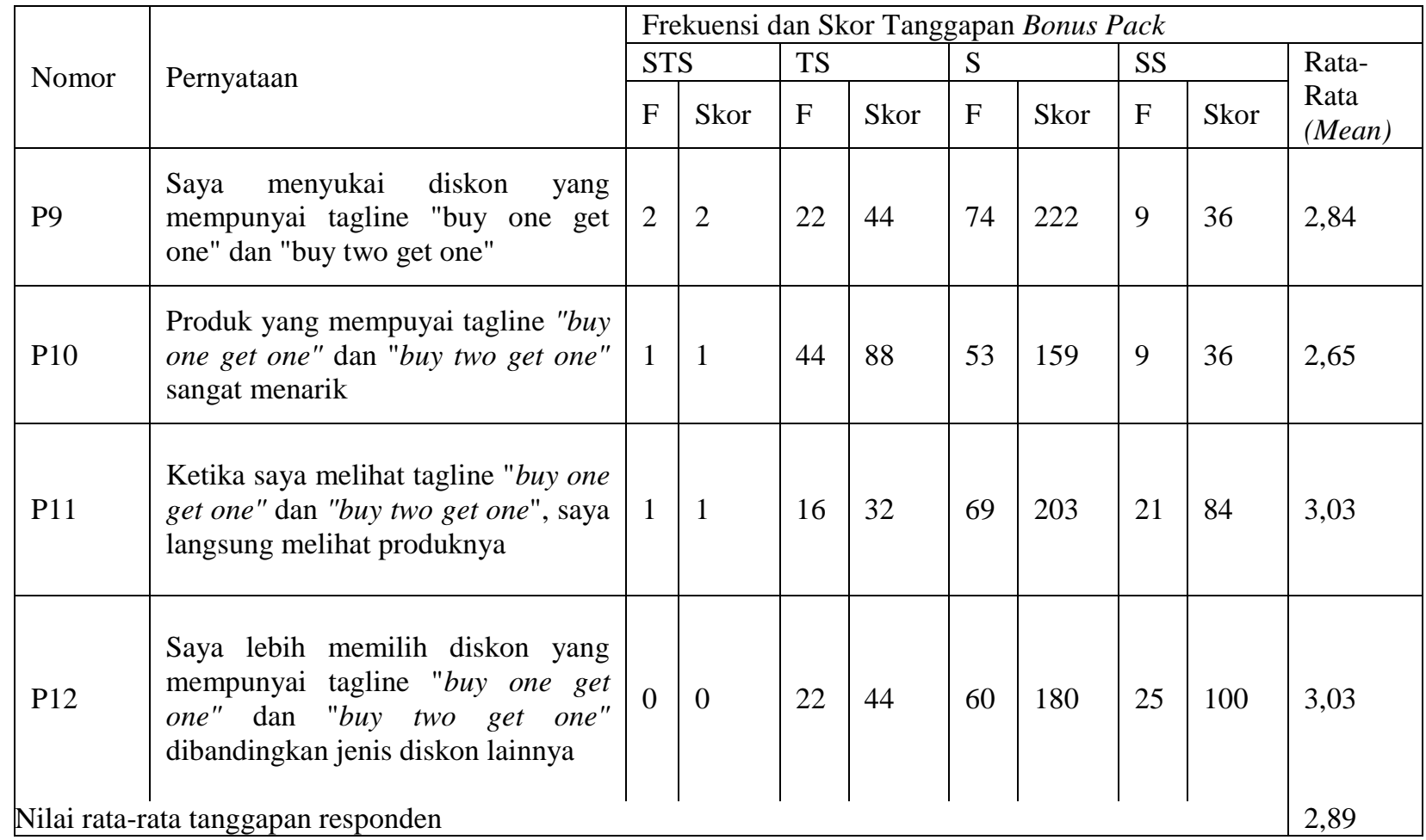

Sumber: Data olahan, 2018 
Journal of Applied Business Administration Vol 3, No 1, Maret 2019, hlm. 132-147.

Penilaian responden mengenai bonus pack adalah baik, dapat dilihat dari nilai rata-rata sebesar 2,89. Responden memberikan apresiasi penilaian tertinggi pada item ketika saya melihat tagline "buy one get one" dan "buy two get one", saya langsung melihat produknya dan saya lebih memilih diskon yang mempunyai tagline "buy one get one" dan "buy two get one" dengan rata-rata sebesar 3,03 (baik), ini berarti responden memiliki minat yang tinggi terhadap tagline buy one get one atau buy two get one karena responden dikarenakan biasanya responden akan merasa diuntungkan karena mendapat produk secara gratis ketika membeli satu produk. Sedangkan item Produk yang mempuyai tagline "buy one get one" dan "buy two get one" sangat menarik merupakan penilaian terendah sebesar 2,65 tetapi masih dalam kategori baik, hal ini karena responden masih beranggapan bahwa masih ada jenis diskon yang lebih menarik dibandingkan bonus pack. Sedangkan tanggapan responden terhadap pertanyaan dalam menilai pelaksanaan special price dapat dilihat pada tabel 8 berikut.

Tabel 8. Tanggapan Responden mengenai Special Price pada Ramayana Department Store, Jodoh, Batam

\begin{tabular}{|c|c|c|c|c|c|c|c|c|c|c|}
\hline \multirow{3}{*}{ Nomor } & \multirow{3}{*}{ Pernyataan } & \multicolumn{9}{|c|}{ Frekuensi dan Skor Tanggapan Special Price } \\
\hline & & \multicolumn{2}{|c|}{ STS } & \multicolumn{2}{|c|}{$\mathrm{TS}$} & \multicolumn{2}{|l|}{$\mathrm{S}$} & \multicolumn{2}{|l|}{$\mathrm{SS}$} & \multirow{2}{*}{$\begin{array}{l}\text { Rata- } \\
\text { Rata } \\
(\text { Mean })\end{array}$} \\
\hline & & $\mathrm{F}$ & Skor & $\mathrm{F}$ & Skor & $\mathrm{F}$ & Skor & $\mathrm{F}$ & Skor & \\
\hline P13 & $\begin{array}{l}\text { Saya tertarik dengan } \\
\text { potongan harga di } \\
\text { waktu-waktu } \\
\text { tertentu }\end{array}$ & 2 & 1 & 34 & 68 & 56 & 168 & 15 & 60 & 2,79 \\
\hline P14 & $\begin{array}{l}\text { Produk yang } \\
\text { menampilkan tagline } \\
\text { Special price sangat } \\
\text { menarik }\end{array}$ & 0 & 0 & 26 & 42 & 74 & 222 & 7 & 28 & 2,82 \\
\hline $\mathrm{P} 15$ & $\begin{array}{l}\text { Ketika saya melihat } \\
\text { tagline harga khusus } \\
\text { dan atau dengan } \\
\text { waktu-waktu } \\
\text { tertentu, saya akan } \\
\text { langsung melihat } \\
\text { produknya }\end{array}$ & 0 & 0 & 32 & 64 & 47 & 141 & 28 & 112 & 2,96 \\
\hline P16 & $\begin{array}{l}\text { Saya lebih memilih } \\
\text { diskon harga khusus } \\
\text { dibandingkan } \\
\text { dengan jenis diskon } \\
\text { lainnya }\end{array}$ & 5 & 5 & 17 & 34 & 66 & 198 & 19 & 76 & 2,93 \\
\hline \multicolumn{10}{|c|}{ Nilai rata-rata tanggapan responden } & 2,88 \\
\hline
\end{tabular}

Penilaian responden terhadap special price adalah baik, dapat dilihat dari nilai rata-rata sebesar 2,88. Responden memberikan penilaian tertinggi sebesar rata-rata 2,96 (baik) pada pernyataan ketika saya melihat tagline harga khusus dan atau dengan waktuwaktu tertentu, saya akan langsung melihat produknya. Sedangkan responden 
Diska, Sri, Pengaruh Price Discount Framing Terhadap Purchase Intention Pada Ramayana....

memberikan penilaian terendah pada pernyataan saya tertarik dengan potongan harga di waktu-waktu tertentu sebesar ratarata 2,79 tetapi masih dalam kategori baik, hal ini karena responden masih beranggapan bahwa masih ada jenis diskon yang lebih menarik dibandingkan special price. Analisis deskriptif penilaian mengenai purchase intention dapat dilihat dari hasil nilai frekuensi dan skor jawaban responden terhadap pertanyaan yang diajukan. Rinciannya seperti pada tabel 9 berikut.

Tabel 9. Tanggapan Responden mengenai Purchase intention pada Ramayana Department Store, Jodoh, Batam

\begin{tabular}{|c|c|c|c|c|c|c|c|c|c|c|}
\hline \multirow{3}{*}{ Nomor } & \multirow{3}{*}{ Pernyataan } & \multicolumn{9}{|c|}{ Frekuensi dan Skor Tanggapan Purchase intention } \\
\hline & & \multicolumn{2}{|c|}{ STS } & \multicolumn{2}{|l|}{ TS } & \multicolumn{2}{|l|}{$S$} & \multicolumn{2}{|l|}{ SS } & \multirow{2}{*}{$\begin{array}{l}\text { Rata- } \\
\text { Rata } \\
\text { (Mean) }\end{array}$} \\
\hline & & F & Skor & $\mathrm{F}$ & Skor & $\mathrm{F}$ & Skor & $\mathrm{F}$ & Skor & \\
\hline P17 & $\begin{array}{l}\text { Saya terkesan dengan } \\
\text { produk pakaian tas dan } \\
\text { sepatu di Ramayana } \\
\text { Department Store }\end{array}$ & 0 & 0 & 8 & 16 & 88 & 264 & 11 & 44 & 3,03 \\
\hline P18 & $\begin{array}{lr}\text { Saya tertarik } & \text { dengan } \\
\text { macam-macam } & \text { produk } \\
\text { dan merk yang } \\
\text { ditawarkan } & \text { di } \\
\text { Ramayana } & \text { Department } \\
\text { Store } & \\
\end{array}$ & 5 & 5 & 51 & 102 & 47 & 141 & 4 & 16 & 2,47 \\
\hline P19 & $\begin{array}{l}\text { Saya akan mencari tahu } \\
\text { tentang produk } \\
\text { pakaaian tas dan sepatu } \\
\text { yang ditawarkan di } \\
\text { Ramayana Department } \\
\text { Store }\end{array}$ & 1 & 1 & 21 & 42 & 75 & 225 & 10 & 40 & 2,88 \\
\hline P20 & $\begin{array}{l}\text { Saya akan mencari tahu } \\
\text { tentang pengalaman } \\
\text { belanja produk pakaian } \\
\text { tas dan sepatu melalui } \\
\text { teman dan media di } \\
\text { Ramayana Department } \\
\text { Store }\end{array}$ & 2 & 2 & 6 & 12 & 84 & 252 & 15 & 60 & 3,05 \\
\hline $\mathrm{P} 21$ & $\begin{array}{lr}\text { Saya mempunyai } \\
\text { keinginan untuk } \\
\text { memiliki produk } \\
\text { pakaian, tas dan sepatu } \\
\text { yang ada di Ramayana } \\
\text { Department Store } \\
\end{array}$ & 1 & 1 & 12 & 24 & 47 & 141 & 47 & 188 & 3,31 \\
\hline $\mathrm{P} 22$ & $\begin{array}{l}\text { Saya akan menjadikan } \\
\text { produk pakaian tas dan } \\
\text { sepatu di Ramayana } \\
\text { Department Store } \\
\text { sebagai referensi utama }\end{array}$ & 1 & 1 & 11 & 22 & 63 & 189 & 32 & 128 & 3,18 \\
\hline $\mathrm{P} 23$ & $\begin{array}{l}\text { Saya akan memberi } \\
\text { produk pakaian, tas dan } \\
\text { sepatu dalam waktu } \\
\text { dekat di Ramayana } \\
\text { Department Store }\end{array}$ & 0 & 0 & 37 & 74 & 70 & 210 & 0 & 0 & 2,65 \\
\hline
\end{tabular}


Journal of Applied Business Administration Vol 3, No 1, Maret 2019, hlm. 132-147.

\begin{tabular}{|l|l|l|l|l|l|l|l|l|l|l|}
\hline & $\begin{array}{l}\text { Macam-macam produk } \\
\text { dan merk yang } \\
\text { ditawarkan rem di } \\
\text { Ramayana Department } \\
\text { Store menjadi penentu } \\
\text { saya dalam keputusan } \\
\text { pembelian produk }\end{array}$ & 1 & 1 & 52 & 104 & 54 & 162 & 0 & 0 & 2,50 \\
\hline P25 & $\begin{array}{l}\text { Keinginan saya untuk } \\
\text { memliki produk yang } \\
\text { ditawarkan di } \\
\text { Ramayanan sangat } \\
\text { tinggi }\end{array}$ & 0 & 17 & 34 & 85 & 255 & 5 & 20 & 2,89 \\
\hline P26 & $\begin{array}{l}\text { Harga menjadi saslah } \\
\text { satu penentu saya } \\
\text { dalam membeli produk }\end{array}$ & 13 & 13 & 22 & 44 & 40 & 120 & 32 & 128 & 2,85 \\
\hline Nilai rata-rata tanggapan responden
\end{tabular}

Sumber: Data olahan, 2018

Penilaian responden terhadap Purchase intention adalah baik, dapat dilihat dari nilai rata-rata sebesar 2,88. Responden memberikan penilaian tertinggi sebesar ratarata 3,31 (sangat baik) pada pernyataan Saya mempunyai keinginan untuk memiliki produk pakaian, tas dan sepatu yang ada di Ramayana Department Store. Sedangkan responden memberikan penilaian terendah pada pernyataan Saya tertarik dengan macam-macam produk dan merk yang ditawarkan di Ramayana Department Store sebesar rata-rata 2,47 (tidak baik), karena pengunjung lebih tertarik dengan harga dibandingkan dengan merek.

Variabel percentage discount diperoleh t hitung sebesar 12,486 dengan signifikansi sebesar 0,000 (sig < 0,05). Hasil penelitian tersebut menunjukkan angka signifikansi lebih kecil dari 0,05 dan $\mathrm{t}$ hitung sebesar $12,486>t$ tabel sebesar 1,982, maka variabel percentage discount berpengaruh positif dan signifikan terhadap variabel purchase intention. Hasil uji hipotesis membuktikan bahwa absolute saving berpengaruh positif dan signifikan terhadap purchase intention, dengan hasil uji t sebesar 1,238 dengan sig. $0,000<\alpha=0,05$. Hasil uji hipotesis membuktikan bahwa variabel bonus pack berpengaruh positif dan signifikan terhadap purchase intention dengan hasil uji t sebesar
8,215 dengan sig. $0,000<\alpha=0,05$. Pembelian produk dengan bonus pack promotion sangat menguntungkan karena mereka mendapatkan kuantitas atau produk tambahan dengan harga normal atau harga serupa ketika konsumen melakukan pembelian ketika tidak ada promosi bonus pack. Pelanggan menikmati bonus pack karena rasanya seperti mereka mendapatkan gratis barang dagangan. Berdasarkan nilai uji $\mathrm{t}$ sebesar 8,215 dengan sig. $0,000<\alpha=0,05$, sehingga hipotesis bahwa special price berpengaruh positif dan signifikan terhadap purchase intention diterima.

Hasil pembahasan penelitian menunjukkan bahwa semua variabel price discount framing berupa percentage discount, absolute saving, bonus pack dan special price berpengaruh positif dan signifikan terhadap variabel purchase intention dengan skor mean adalah baik. Hal ini selaras dengan penelitian sebelumnya yang berjudul "Pengaruh price discount framing terhadap purchase intention (studi eksperimen pada Mahasiswi Fakultas Ekonomi dan BisnisUniversitas Lampung)" oleh Elsa Yuni Hercia (2017), tetapi memiliki perbedaan di variabel manakah yang lebih berpengaruh, dimana pada penelitian sebelumnya absolute saving lebih berpengaruh dibandingkan variabel lainnya. 
Diska, Sri, Pengaruh Price Discount Framing Terhadap Purchase Intention Pada Ramayana....

Sedangkan dalam penelitian ini dengan skor mean 2,98 menunjukkan bahwa percentage discount adalah variabel yang paling berpengaruh dibandingkan dengan variabel absolute saving, bonus pack dan special price.

Hasil perhitungan statistik menunjukkan nilai $\mathrm{f}_{\text {hitung }}=63,552$ dengan derajat signifikan $0,000<0,05$ dan $\mathrm{f}_{\text {tabel }} 2,46$ sehingga diperoleh nilai $\mathrm{f}_{\text {hitung }} 63,552>\mathrm{f}_{\text {tabel }}$ 2,46 maka H0 ditolak dan H5 diterima yang berarti secara simultan variabel percentage discount, absolute saving, bonus pack dan special price mempunyai pengaruh yang positif dan signifikan terhadap purchase intention.

Berdasarkan analisis koefisien determinasi didapat $\mathrm{R}$ square sebesar 0,714 artinya $71,4 \%$ purchase intention dipengaruhi oleh variable percentage discount, absolute saving, bonus pack dan special price. Berarti $28,6 \%$ dipengaruhi oleh variabel-variabel lain yang tidak dibahas dalam penelitian ini.

\section{SIMPULAN DAN SARAN}

Berdasarkan pembahasan hasil penelitian diatas dapat ditarik kesimpulan bahwa percentage discount, absolute saving, bonus pack dan special price memiliki pengaruh yang positif dan signifikan secara parsial dan simultan terhadap purchase intention di Ramayana Department Store. Adapun saran berdasarkan hasil penelitian bahwa tingginya pengaruh percentage discount, absolute saving, bonus pack dan special price terhadap purchase intention, maka Ramayana Department Store sebaiknya semakin meningkatkan lagi pelaksanaan price discount framing sehingga purchase intention konsumen semakin meningkat yang pada akhirnya akan meningkat volume penjualan Ramayana Department Store. Sedangkan rekomendasi untuk penelitian selanjutnya diharapkan bahwa penelitian purchase intention sebaiknya menambah lagi variabel bebasnya dan menggunakan teknik wawancara dalam mengumpulkan data penelitian agar data penelitian dapat menggambarakan kondisi yang sesungguhnya.

\section{DAFTAR PUSTAKA}

Bearman. (2007). Retail Managemen :A Strategic Approch. Englewood Cliffs. Daryanto. (2010). Media Pembelajaran . Jakarta: Gava Media.

Gemiliel and Herstein. (2011). to save or to loose. does framing price promotion affect consumer Purchase intention Journal of consumer marketing , Vol.28 No.2.

Kotler Philip, Amstrong Gary. (2013). Prinsip-prinsip Pemasaran, Edisi ke12. Erlangga.

Kotler and Amstrong. (2010). Prinsipprinsip Pemasaran Jilid 1 \& 2 Edisi 12. Jakarta: Gramedia.

Sugiyono. (2014). Metode Penelitian Pendidikan Pendekatan Kuantitatif, Kualitatif, dan $R \& D$. Bandung: Alfabeta.

Swasta, B. (2008). Manajemen Pemasaran Modern . Jogjakarta: Liberty Jogianto, $\mathrm{H}$.

Tjiptono, F. (2008). Strategi Pemasaran, edisi ketiga.

$\mathrm{Wu}$, Chin \& Cheng, Fei Fei. (2011). The Joint Effect of Framing and Anchoring on Internet Buyers' Decision Making. Electronic Commerce Research and Aplication. 